\title{
6. What is happening to investigative journalism? A pilot study of ABC's Four Corners
}

\section{ABSTRAACI}

The purpose of investigative journalism is to hold powerful interests to account and highlight systemic corruption and breakdown. Ettema and Glasser, and de Burgh, define the investigative journalist's role as to bring attention to injury and injustice, expose information that is in the public interest, and encourage legislative reform. As traditional media models falter in response to the popularisation of the internet, it is argued that quality and investigative journalism is in decline. Little empirical research has been undertaken which can help answer the question of whether such claims are justified or not. As a preliminary step to establishing a methodology for undertaking such research, a pilot study investigated the amount of investigative journalism produced by ABC Television's premier current affairs programme Four Corners, which claims to be a platform for investigative journalism. Two data sets were the subject of content analysis, in which definitions of investigative journalism of Ettema and Glasser, de Burgh and others were used to create categories for analysis. Results indicate that only half of the journalism produced by the programme can be defined as investigative journalism.

Keywords: content analysis, investigative journalism, methodologies, public broadcasting, television, quality journalism

\section{MARNI CORDELL}

Editor, New Matilda

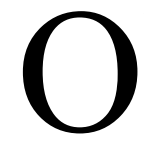

VER recent years, a debate has been taking place between journalists, editors, media producers and proprietors about the effect of the internet on the production and profitability of 'quality' and investigative journalism (Este, 2009). Much of the commentary in the 'future of 
journalism' debate assumes that there has been a decline in the amount of quality and investigative journalism being produced by Australian outlets in recent years (Beecher, 2009; Scott 2009). However, there is little research that provides a methodology to test these claims. In order to be useful to both media researchers and to those working as practitioners within the industry, the debate needs to be anchored in empirical research.

The research project on which this article is based uses content analysis to determine how much of the journalism produced by Four Corners can be defined as investigative journalism according to the definitions provided by Ettema \& Glasser (1998), de Burgh (2008) and others (Spark 1999; de Fleur 1997) - and whether that has changed between 2002 and 2009. Four Corners was chosen as the subject of the study because the programme bills itself as 'Australia's premier television current affairs programme', providing 'Investigative TV journalism at its best' (www.abc.net.au/4corners 2009). The project is a pilot study, and while it is not intended to be exhaustive, it does propose a methodology for testing claims about a decline in investigative journalism - as well as provide a framework for a discussion about the state of investigative journalism in Australia in late 2009.

\section{Context for this research: A decline in 'quality' journalism?}

The global concern for the future of good, original journalism is not flippant, nor is it just media commentators who are providing the fodder for the 'future of journalism' debate. Practitioners are also concerned: investigative journalists gathered at the annual Investigative Reporters and Editors conference as early as 2002 reported feeling grim about the future of their craft, and described an industry that was beginning to care 'more about profits than Pulitzers' (Aucoin, 2005, p. 1). In Australia, the Media Entertainment and Arts Alliance (MEAA) has launched the Future of Journalism project, which tracks changes to the industry and aims to minimise the negative impact on media practitioners (www.thefutureofjournalism.org.au/).

The popularisation of the internet in the past 15 years has diminished the revenue base of many corporate media outlets, particularly broadsheet newspapers, which have traditionally relied on classified advertising to cover their substantial running costs (The Economist, 2006), and this has led to costcutting across the board. The amount of journalists in fulltime positions has diminished in recent years, and many of those who remain have been required 
to reskill or multi-task to take on broader roles within the news organisation (Este, 2009). Audiences are also going online, although evidence suggests that this is in fact less of a problem than is widely perceived. Research in the United States found that only 5 percent of people get their news from the internet only - most people still use their traditional sources of news and information, as well as the internet (The Economist, 2006). However, there is no doubt that as advertisers take their products online, the revenue base of one of the traditional homes of serious journalism - the broadsheet newspapershas diminished (Beecher, 2009; The Economist, 2006). As it becomes clear that online advertising alone cannot support good original journalism (The Economist, 2006), the debate both in Australia and globally has now turned to the best way to finance its production into the future.

It has been suggested by some media commentators that Australia needs a publicly funded newspaper to fill the gap in the market that will be left by the decline of commercial newspapers (Sparrow, 2009; Beecher, on ABC Radio, 2009). However, there has been little scrutiny by these same commentators of the journalism that the taxpayer already funds - that is, the journalism produced by the public broadcaster. How much of this can be defined as 'quality' or 'investigative', and is the $\mathrm{ABC}$ looking at ways to increase this output in response to an industry in decline? Indeed, how does the public broadcaster intend to fulfill its legislated role to step in where the market fails?

\section{Defining investigative journalism}

Not all of what is being referred to in the future of journalism debate as 'quality journalism' can also be defined as investigative journalism-according to Crikey publisher Eric Beecher, the term also encompasses 'analysis and feature writing, commentary, opinions, editorials, campaigns as well as the day-to-day reporting of parliaments, councils, courts, tribunals, wars, stock exchanges and all the other tentacles of the polity, the judiciary and the democracy' (2009). However, like investigative journalism, quality-or 'public trust' (Beecher, 2009)—journalism 'applies scrutiny, analysis and accountability to governments, parliaments, politicians, public servants, judges, police, councils, the military, NGOs, diplomats, business and community leaders and the recipients of public funding' (Beecher, 2009).

Alan Kohler, publisher of the Business Spectator, has argued that 'most of what is called quality journalism is not quality at all-it is leaks, planted 
by vested interests, to journalists who need to stay onside with those interests (politicians, sports administrators, business people etc)...' (Kohler, 2009). Investigative journalism operates outside of this cycle and in doing so plays an important role in bringing attention to systemic corruption and abuse of power (de Burgh, 2008). When wrongdoing takes place, experience shows that it is the investigative journalist who is best placed to expose it and ensure that justice is done (Knight, 2007). Importantly, in the context of the future of journalism debate, it is also investigative journalism that provides the least return for investment and is therefore the first to suffer from media cutbacks (The Economist, 2006).

In defining investigative journalism, it is illustrative to examine its relationship to those in positions of power and to compare this relationship to that of the daily news journalist. Whereas the daily news journalist receives information from authoritative sources such as governments, courts, police and bureaucracies, and applies news values to prioritise and organise the presentation of this information, it is the investigative journalist's job to 'look beyond what is conventionally acceptable, behind the interpretations of events provided for us by authorities and the authoritative...' (Ettema \& Glasser, 1998, p. 3) and to test the claims made by those in positions of power beyond mere allegation and denial (Ettema \& Glasser, 1998). The daily reporter tends to accept official statements as true - or if not true, then at least as worthy of reporting as news (Tuchman, 1978; Ettema \& Glasser 1998). Conversely, the investigative journalist's role is to test claims made by those in power. Ettema and Glasser write that daily reporters 'often don't have to decide what they believe to be true in the same way that investigative reporters have to decide... daily reporters take responsibility for the accurate transcription of official discourse but not the veracity of that discourse' (1998, p. 158) [author's italics].

Investigative journalism uncovers new information through original research that would only have come to the public's attention through the journalist's initiative (Ettema \& Glasser, 1998). However, that new information is not always the result of a 'deep throat' style leak. In fact, the type of investigative journalism that relies on whistleblowers and anonymous sources is much less common than another type: that which brings together new information, or even information that is already in the public domain, in a way that is revelatory (Schapiro, personal 


\section{PUBLIC RIGHT TO KNOW}

communication, 21 April 2009). In many cases, the originality in a piece of investigative journalism comes from 'discovering patterns and connections in the information that no one has observed before', rather than the exposure of scandalous information (Knight, 2007).

Even if investigative journalists are less autonomous in identifying wicked things and inspiring moral umbrage than popular culture might have us believe, they may nevertheless be expanding our ideas of what we should think or care about, making us think in a certain way about an event or issue. (de Burgh, 2008, p. 18)

Another common definition of investigative journalism is 'going after what someone wants to hide' (De Burgh, 2008, p. 15). The investigative journalist seeks to uncover facts that somebody is trying to suppress, using not just direct sources of information, but also less obvious informants 'who know about disturbing secrets and are angry or disturbed enough to divulge them' (Spark, 1999, p. 6). However, it could be argued that the definition of deliberate suppression needs to be updated and is too narrow a focus for investigative reporting as it is developing today (de Fleur, 1997). A more appropriate definition is that investigative reporting 'concerns those matters that are important to the public and not easily discovered' (de Fleur 1997, p.18) [author's italics].

That said, not all information that someone wants to hide - or that is otherwise difficult to find - is necessarily worthy information for an investigative journalism to pursue (de Burgh, 2008). Here it is necessary to draw a distinction between investigative journalism and exposure journalism — although it should be noted that we are unlikely to find examples of the latter masquerading as the former on Four Corners; this kind of journalism is much more common on the commercial channels. Former Guardian editor Alan Rusbridger suggests that it is the 'quality of the target' (de Burgh, 2008, p. 15) that distinguishes investigative journalism from exposure journalism. De Burgh writes that investigative journalists 'expose, but they expose in the public interest', a good test of which is whether the information uncovered contributes to the public's understanding of the target in a way that will inform their opinion of the target's capacity as a public official, role model or otherwise powerful person (2008, p. 23).

More than other types of journalism, investigative journalism calls on us as audience members to use our moral intelligence and to examine 'the 
breakdown of social systems and the disorder within public institutions that cause injury and injustice' (Ettema \&Glasser, 1998, p. 3). In most cases, rather than focusing on an individual case of grievance, an investigative journalist will choose stories that transcend the facts of a particular case and illustrate a broader trend or failure of a system (Ettema \& Glasser, 1998, p. 3). 'They are doing more than disagreeing with how society runs; they are pointing out that it is failing by its own standard,' (de Burgh, 2008, p. 23). In this way, the investigative journalist calls on public officials and lawmakers - as well as the public itself - not only to care about instances of injustice, but also to act on them. De Burgh argues that investigative journalism provides 'the first rough draft of legislation', by drawing attention to 'the failures within society's system of regulation and to the ways in which those systems can be circumvented by the rich, the powerful and the corrupt' $(2008$, p. 3$)$. Finally, the target of the investigative journalist's work is typically in a position of power or is a public figure of some kind-this can also be collective, such as a government or another powerful entity such as a corporation. 'There is ... always a victim and, even if it is collective, always a villain to blame' (de Burgh, 2008, p. 14).

In summary, according to the definitions provided by Ettema and Glasser (1998), de Burgh (2008) and others (Spark, 1999; de Fleur, 1997), this research adopted the position that for a story to be classified as investigative journalism it must possess the following characteristics:

1. The target of the story must be a public figure and/or a person or group in a position of power (can be collective), and the information revealed about that target must be in the public interest.

2. The story must reveal information that someone wants suppressed and/or is for other reasons concealed from the public that would only have been uncovered through the journalist's initiative.

3. The journalist must seek to pursue the issue beyond allegation and denial.

4. The story must reveal new information and/or bring together information that is already in the public domain in a way that is revelatory.

5. The story must alert us to systemic failures and/or point out where society is failing/or falling short of purported standards. 


\section{Research methodology}

Taking the five points above as categories for analysis, a content analysis was conducted of the Four Corners stories. Although content analysis was traditionally limited to manifest content only-that is, 'elements that are physically present and countable' (Neuendorf, 2002, p. 420), it has become common for it to be applied to latent content, or concepts that 'cannot be measured directly but can be represented or measured by one or more... indicators' (Neuendorf, 2002, p. 581). Rather than analysing the amount of times a word or topic was present, the analysis examined what indicators or characteristics of investigative journalism techniques were used to construct the story in question. This methodology is similar to that used by McLachlan and Golding in Tabloidization in the British Press: A Quantitative Investigation into Changes in British Newspapers, 1952-1997 (2000). In this study, the researchers identified 'tabloid' indicators and used these to measure 'tabloidisation' in the British press.

In constructing the five mutually exclusive categories above, Wimmer and Dominick's advice was followed that 'all category systems should be mutually exclusive, exhaustive and reliable' (2000, p. 177). Categories must also be exhaustive: that is, there must be a category for every unit of analysis (Wimmer \& Dominick, 2000). Initially, six categories were developed and tested against two Four Corners stories. Through testing, it was discovered that one of the criteria - that investigative journalism always has both a victim and a villain - was redundant as it was not mutually exclusive from another criteria: that investigative journalism has as its target those in positions of power.

The aim was to analyse and compare results from two different years. It was not possible within the scope of this project to analyse every episode broadcast within two 12-month periods, so instead I used a representative sample, which, if properly selected can give an adequate description of a large amount of content (Budd, Donohew \& Thorpe, 1967). Neuendorf's suggestion of using a random sample even for a small content analysis was followed (Neuendorf, 2002) by using a random number generator to pick 15 stories from each of two periods: the 12 months leading up to 15 May 2009 (when this study was undertaken), and the 12 months of 2002. Four Corners broadcasts roughly 40 stories a year, so 15 stories constitutes just under a third of the show's annual output. 
In choosing the data sample, episodes were selected only from those that have been archived online (all stories broadcast since January 2000). In a larger study, recent broadcasts could be compared with those of 1982, 83 or 84, when it has been argued that investigative journalism was enjoying a resurgence in Australia and globally (Schultz, 1998; Pullan, 1986). This was not possible within the constraints of this study because it would have required watching VHS tapes on-site at the ABC. I chose the year 2002 because it was politically interesting: it was the lead up to the invasion of Iraq, there was a serious debate about border control taking place in Australia as a result of the 'children overboard affair', and it was also one term into the Howard years, during which the $\mathrm{ABC}$ faced allegations of bias from the Federal Government (Banham, 2002).

Four Corners rebroadcasts a number of stories that have been purchased from overseas broadcasters. As this research project aims to analyse the success of Australian public funds in supporting the production of investigative journalism, 'buy-ins' were excluded from the analysis. Also, in this age of global media reach, it is arguable that the rebroadcasting of television content from overseas broadcasters has become redundant, since the internet has made this content relatively easy to access from anywhere in the world. This was even more the case in 2008-9 than in 2002.

The raw data used for the coding of the 30 stories was the transcripts and video (where available) on the programme's website (www.abc.net. $\mathrm{au} / 4$ corners/). Unless it was bought from another source, each programme was measured against the five criteria of investigative journalism.

\section{Results}

Coding of the 2002 data set revealed that eight out of 15 stories met all of the criteria for investigative journalism, three met some or none of the criteria for investigative journalism, and four of the stories were bought in, all from the BBC's Panorama programme. Coding from the second data set, which covered the past 12 months, revealed that seven stories met all the criteria for investigative journalism, four stories met some or none, and four of the stories were bought in: two from Channel Four, one from the BBC and one from an independent production house. Overall, 15 out of 30, or 50 percent of stories, met all five criteria for investigative journalism. When the two data sets were compared, there were slightly more stories that met all the 
criteria for investigative journalism in the 2002 data set than there were in the 2008-09 set, but because the results are in fact similar, it was difficult to draw a conclusion (Wimmer \& Dominick, 2000) about whether there had been a decline in the amount of investigative journalism being produced by Four Corners between 2002 and now. As suggested above, it could be argued that the practice of buying in programmes is less justified than previously and the proportion of these imports raised questions that could be pursued in further research about whether they are used as fill-ins for budgetary reasons. What can be concluded from this pilot study is that for a programme that bills itself as 'investigative TV journalism at its best', Four Corners only partially fulfils it claims.

Among those stories that met all the criteria were classic investigative pieces such as Chris Masters' 'The God of Broken Hearts' (2008). This report on the Brisbane Christian Fellowship uncovers instances of abuse going on within a cult-like Christian church. In the story, Masters offers right of reply to the church (it is refused) but he also seeks to prove the allegations of abuse by using multiple sources (de Burgh, 2008) including eyewitness accounts, expert opinion, internal documents and medical opinion citing increased instances of stress and breakdown among members and ex-members of the church. The target is in a position of power and the story exposes information that someone wants to hide or is otherwise concealed from the public. There would be little scope to argue that the content is merely of private interest rather than a matter of concern in the public interest. The story also looks at the broader issue of religious freedom and looks at the legislative framework that exists for monitoring such groups, thereby calling on the audience to consider the systemic failure that has allowed these events to take place (Ettema \& Glasser, 1998).

Other stories were not so straightforward to code. 'Bran Nue Deal' by Matthew Carney (2008) is a report about a prospective gas plant in the Kimberly and attempts by a local indigenous leader to negotiate part local ownership. The report also details opposition to the plant from green groups and tourist operators. The subject matter of this report had the potential to be investigative - the material could have been interrogated in such a manner that revealed hidden information and exposed vested interests. However, in coding, the report met only one of the criteria for investigative journalism: that it reveals new information and/or brings together information that is 
already in the public domain in a way that is revelatory. The story consists predominantly of interviews with people who are both for and against the prospective refinery and how it will affect their lives and livelihood. It provides historical and cultural context for the issue and details some interesting facts about the environmental uniqueness of the proposed site. However, the reporter does not seek to expose concealed or suppressed information, nor does he scrutinise the power brokers behind the project (de Burgh, 2008) or look in any detail at who stands to benefit from it. There is no discernable 'target' and the story is not illustrative of a systemic failure. (It is worth noting, however, that this should not be taken as a reflection of Matthew Carney's work as an investigative reporter-he has demonstrated on both Four Corners and other programmes that he is proficient in the genre.).

Sarah Ferguson's report 'Buying Back the River' (2008) also canvasses opinions - this time of the Rudd government's Murray Darling water buyback scheme, which has seen the government spend millions of dollars on buying back water-entitlement permits that were once given away for free. However, unlike Carney's 'Bran Nue Deal', this report reveals information that has been suppressed or is otherwise being concealed from the public, and would not have been revealed without the journalist's initiative - the most important of which is a loophole that allows for profiteering in the scheme by state governments, as a result of a hangover from a federal-state arrangement. The Federal Water Minister, Penny Wong, denies the loophole is exploitable, but Ferguson goes to other sources to ascertain that in fact it is. This is important new information that the government would prefer was not made public. Again, few would argue, the story was not a matter of public concern, and it raises an issue of systemic failure (Ettema \& Glasser, 1998). When coded, Ferguson's report met all five criteria for investigative journalism.

'Beautiful One Day' (2002) by Stephen McDonnell, is a report on the effect of climate change and other environmental factors on the Great Barrier Reef. One of the constraints on coding stories within the 2002 data set was my knowledge of what was and wasn't new information at that time. When coding this story I had to refresh my memory about how much information had already been in the media on the issue of climate change and damage to the Great Barrier Reef. The report brings together both new and existing information from the scientific, fishing and farming sectors in a way that is revelatory. It also reveals information that is in the public interest, illustrates 
a systemic failure and has been suppressed by a public figure: documents obtained through freedom of information that show co-operation between the Federal government and oil companies on oil exploration within the Great Barrier Reef marine park. However, these documents were in fact obtained by another journalist, who McDonnell interviewed about her findings. The information was therefore not obtained through the journalist's own initiative (Ettema \& Glasser, 1998) and had in fact already been reported at the time the story went to air. For this reason, the report met only four of the five criteria for investigative journalism.

In demonstrating that it is not always subject matter so much as treatment of subject matter that makes a piece of journalism investigative (de Burgh, 2008), it is illustrative to compare two reports from the 2002 data set: 'For the Good of the Game' by Ticky Fullerton, a story on the financial crisis within the AFL, and 'Final Whistle' by Quentin McDermott, about financial mismanagement within Soccer Australia. Both stories examined a similar issue: administrative mismanagement within a sporting code, and how this is affecting the game. Both had the potential to be investigative reports, but only one of them met all five criteria for investigative journalism. While Fullerton gathered together accessible data on the financial situation of various AFL clubs, and interviewed key players, McDermott's research uncovers evidence of corporate deals gone wrong and shareholders receiving inaccurate information from Soccer Australia. It also presents details and speaks to key players in a 'coup' that toppled the former head of the sporting body. McDermott's report is an expose that seeks to hold Soccer Australia to account for its failure to effectively manage the code in Australia. When coded, it met all five criteria for investigative journalism. Fullerton's report met only one: that it revealed new information and/or brought together information that is already in the public domain in a way that is revelatory.

There is no doubt that most, if not all, of the journalism that Four Corners produces is of a high standard. This research project did not seek to determine the quality of the journalism produced by Four Corners, but rather, how much of that journalism adhered to the definition of investigative journalism of de Burgh, Ettema and Glasser and other key scholars, and whether that had declined since 2002. In order to draw comprehensive conclusions about a decline in the production of investigative journalism at Four Corners, it would be necessary to do a more substantial study_ideally taking in episodes from 
earlier decades. However, the conclusion that can be drawn from this study is that for a show that bills itself as 'investigative TV journalism at its best', Four Corners has room for improvement.

\section{Conclusion}

The managing director of the ABC, Mark Scott, has spoken on a number of occasions about a crisis in the revenue base for quality journalism, arguing that 'We are in such a state of transformation and turmoil. Much of what we assumed to be true about the media business has been turned on its head' (2009). In relation to the failure of traditional media models, Scott has said of the ABC: 'We can deliver as the market fails - it is one of the reasons we were established' (2009).

Investigative journalism is the most expensive type of journalism that a media organisation can produce: it is time consuming and does not normally provide return on the substantial investment needed to support its production. Because of this, the public broadcaster is well placed to produce this kind of journalism as the media models of the 20th century become unprofitable and redundant. Furthermore, beyond being a good business model to support the production of investigative journalism as the commercial model fails, the ABC has a particular responsibility to step in when the market fails, as outlined in its 1983 charter (www.abc.net.au/corp/pubs/ABCcharter.htm).

In the 2009-10 Federal Budget, the $\mathrm{ABC}$ received a funding boost of A \$167 million over the next three years. According to Scott, the broadcaster will spend this money on drama, a dedicated digital children's television channel, and on so-called 'regional broadband hubs' that will allow user-generated content (ABC, 2009). It is clear from this extra funding and these new plans that the $\mathrm{ABC}$ is in the process of expansion. However, when responding to questions from Fran Kelly on Radio National Breakfast after the Budget announcement, Scott ruled out a dedicated news and current affairs channel in the near future.

Four Corners is the only programme on ABC Television that is billed exclusively as investigative journalism, and as such the show's output can be judged as an indication of the public broadcaster's commitment to producing journalism of this genre. Given that the Australian commercial programme that have clearly identified itself with investigative journalism, Channel 9's Sunday programme, closed in 2008, it would seem an appropriate time for the public 


\section{PUBLIC RIGHT TO KNOW}

broadcaster to invest more resources into this genre of quality journalism.

This pilot study at least would suggest that the ABC has not increased its output to address this change in the media market and recent budget commitments indicate that it does not intend to do so in the near future. In the context of Mark Scott's enthusiastic participation in the future of journalism debate, this is important research to be conducting at this time.

The research also suggests a methodological approach by which claims about investigative journalism's decline or otherwise can be evaluated and grounded in more empirical evidence.

\section{References}

ABC funding boost. (2009, May 12). ABC News. Retrieved in September 2009, from www.abc.net.au/corp/pubs/media/s2568522.htm

Australian Broadcasting Corporation.ABC Charter 1983, Retrieved on 23 May 2009, from www.abc.net.au/corp/pubs/ABCcharter.htm

Aucoin,J.L.(2005).The evolution of American investigative journalism. Columbia: University of Missouri Press.

Banham, C. (2002, October 3). Alston adds fuel to inferno of ABC bias', The Sydney Morning Herald.

Beecher, E. (2009). Democracy and the near death of public trust journalism. Retrieved on 3 May 2009, from www.crikey.com.au/Media-Arts-and-Sports/20090408Democracy-and-the-near-death-of-public-trust-journalism.html

Budd, R.W.; Thorpe, R.K.; and Donohew, L. and Thorpe, Robert K. (1967). Content analysis and communications. New York: The Macmillan Company.

De Burgh, H. (2008). Investigative journalism. London: Routledge.

De Fleur, M. H (1997). Computer assisted investigative reporting: Development and methodology. New Jersey: Lawrence Erlbaum Associates, Publishers.

Este, J. (2008, June/July). 'We Need to Talk', The Walkley Magazine, p. 37.

Ettema, J. and Glasser, T. L (1998). Custodians of conscience: Investigative journalism and public virtue. New York: Columbia University Press.

Forum: Future of Mass Quality Journalism 2009, April 11 Saturday Breakfast Extra, ABC Radio National. Retrieved from www.abc.net.au/rn/saturdayextra/ stories/2009/2539281.htm

Four Corners website Australian Broadcasting Corporation. Retrieved on 31 May 2009, from www.abc.net.au/4corners/

Knight, A. (2007). Online investigative journalism, Retrieved on 31 May 2009, from ejournalist.com.au/v1n1/inv.pdf

McLachlan, S. and Golding, P. (2000). Tabloidization in the British Press. In Sparks, C. and Tulloch, J. (eds.), Tabloid tales: Global debates over media standards (pp. 75-89). Oxford: Rowman and Littlefield. 
Media Entertainment and Arts Alliance (2009). Future of journalism project. Retrieved on 31 May 2009, from www.thefutureofjournalism.org.au

Neuendorf, K. A. (2002). The content analysis guidebook. London/Thousand Oaks, CA: Sage.

Pullan, R. (1986). Four Corners: 25 Years. Sydney: ABC Enterprises.

Schultz, J. (1998). Reviving the fourth estate. New York: Cambridge University Press.

Scott, M. (2009). The Impact of the national broadband network. Retrieved on 23 September 2009, from www.crikey.com.au/Media-Arts-and-Sports/20090409Mark-Scott-lecture.html

Spark, D. (1999). Investigative reporting: A study in technique. Oxford: Focal Press

Sparrow, J. (2009). Why we need a public newspaper. Retrieved in August 2009, from newmatilda.com/2009/08/14/why-we-need-public-newspaper

Who killed the newspaper? (2006, August 24). The Economist. Retrieved in May 2009, from www.economist.com/opinion/displayStory.cfm?Story_ID $=7830218$

Wimmer, R. and Dominick, J. R. (2000). Mass media research: An introduction (6th ed). Boston: Wadsworth.

Marni Cordell is the editor of New Matilda www. newmatilda.com, a news and analysis website in Sydney. This research was conducted as part of her Master of Arts (Journalism) programme at the University of Technology, Sydney. marni.cordell@newmatilda.com 